\title{
A SOCIO-DEMOGRAPHIC REVIEW ON ADOLESCENT DEATHS IN WEST BENGAL
}

\author{
Rina Das ${ }^{1}$ Partha Bhattacharya2 ${ }^{2}$ Somnath Das ${ }^{3}$
}

${ }_{1}^{1}$ Assistant Professor, Department of Forensic Medicine and Toxicology, R. G. Kar Medical College, Kolkata, West Bengal, India. ${ }^{2}$ Associate Professor, Department of Forensic Medicine and Toxicology, R. G. Kar Medical College, Kolkata, West Bengal, India. 3Professor, Department of Forensic Medicine and Toxicology, R. G. Kar Medical College, Kolkata, West Bengal, India.

ABSTRACT

\section{BACKGROUND}

According to W.H.O. adolescence is between age group 10 to 19 when physical \& psychological development occurs. Many health problems develop in this period. The mortality \& morbidity pattern of adolescents has a direct impact on future population. Sociodemographic profile in association with unnatural death of the adolescent has been dealt in this study.

\section{MATERIALS AND METHODS}

Study was done in R. G. Kar Police morgue under FMT department with a sample of 80 cases over 1-year time duration.

\section{RESULTS}

Most affected age group is 15 to 19 years \& victims are mainly students. RTA is the main cause of unnatural death. Burn injury was the commonest cause among the suicidal cases. Association between age and sex of the subjects was compared with the manner of death. The relatively older age groups were seen to be more vulnerable towards accidental deaths.

\section{CONCLUSION}

Suicide is an important cause of death among adolescence. Much attention should be paid to institute preventive measures for reducing accidental death as most of the causes are avoidable.

\section{KEY WORDS}

Adolescent, Unnatural Death, Socio-Demography.

HOW TO CITE THIS ARTICLE: Das R, Bhattacharya P, Das S. A socio-demographic review on adolescent deaths in West Bengal. J. Evolution Med. Dent. Sci. 2018;7(46):4990-4993, DOI: 10.14260/jemds/2018/1110

\section{BACKGROUND}

The World Health Organization defines an adolescent as a person between the ages of 10 and 19 years.(1,2) Adolescence is a transitional stage of physical and psychological human development that generally occurs during the period from puberty to legal adulthood. This period is divided into early10 to 13 yrs., mid-14 to 16 yrs., late- 17 to 19 yrs.(3) Around 1 in every 6 persons in the world is an adolescence i.e. 1.2 billion people are aged 10 to 19 .

Many of the health problems seen in adolescence start during the first decade, emphasizing the need for programming across the life-course. The mortality and morbidity/disability patterns of adolescence reflect the transition from childhood to adulthood and the impact of the developmental processes taking place during this period.

Even if the distribution of skills and autonomy varies within the age groups, adolescents will still grow up and become fundamental contributors to development in any country. But not much work has been done in eastern India yet; nevertheless, this does not rule out the importance of the study to decrease adolescent mortality.

'Financial or Other Competing Interest': None.

Submission 29-09-2018, Peer Review 25-10-2018,

Acceptance 31-10-2018, Published 12-11-2018.

Corresponding Author:

Dr. Partha Bhattacharya

Swaraj Apartment, A179,

Baghajatin, PS-Jadavpur,

Kolkata-700092,

West Bengal, India.

E-mail: somnath-1976@rediff.com

DOI: $10.14260 /$ jemds/2018/1110
For this reason alone, and many more, it is necessary to investigate the levels and causes of adolescent mortality since it has a direct impact on the size and health of the future population.

In this study the authors would like to find out the prevalence of unnatural death, its type and pattern among adolescence and Social-demographic profile of the adolescent population leading to unnatural death. The outcome will try to identify the areas of concern that must be dealt with by the different organizations of the administration.

\section{Aims \& Objectives}

1. To enumerate the autopsy findings of unnatural death among the deceased adolescents.

2. To enumerate the manner of deaths among the deceased adolescents.

3. To identify any association between the aetiology of unnatural deaths with Socio demographic profile of the deceased.

\section{MATERIALS AND METHODS}

\section{Study Area}

1. R.G. Kar Police Morgue

2. Department of Forensic Medicine \& Toxicology, R. G. Kar Medical College.

\section{Study Population}

Inclusion Criteria

Within the age of 10 to 19 years coming to R. G. Kar Police Morgue from different police stations under the jurisdiction of the Morgue. 


\section{Exclusion Criteria}

Grossly decomposed and mutilated bodies

\section{Study Duration}

One year.

\section{Study Period}

May 2017 to April 2018.

\section{Sample Size}

The sample size is 80 and is chosen depending on the inclusion and exclusion criteria.

\section{Sample Design}

Every subject who fits with the inclusion and exclusion criteria is taken from the study population.

\section{Study Design}

The study is descriptive Study.

Parameters to be studied

1. Cause of death of adolescents.

2. Manner of death among adolescence.

3. Socio-demographic parameters: based on Prasad scale 2015.

\section{Study Tools}

Relevant documents of post mortem reports and inquest reports, other documents required for data collection.

\section{Operational Definition}

For this study some definitions were adopted:

Adolescents were classified as follows

- 'Younger'- within the age range of 10-14 years.

- 'Late/older'- in the age group 15-19 years. ${ }^{14}$.

The Causes of unnatural deaths were classified as follows

- 'Accidental deaths'-deaths due to accidents like RTA, snake bite, drowning, fall from height, lightning etc.

- Suicide'- death due to deliberate self-harm to end one's life

- 'Homicide'-death caused by the foul play by others

RESULTS

\begin{tabular}{|c|c|c|}
\hline Sex & Frequency & Percent \\
\hline Male & 40 & 50 \\
\hline Female & 40 & 50 \\
\hline Table 1. Frequency and Percentage Wise Distribution of \\
Victims of Different Sex \\
\hline
\end{tabular}

\begin{tabular}{|c|c|c|}
\hline Religion & Frequency & Percent \\
\hline Hindu & 47 & 59 \\
\hline Muslim & 33 & 41 \\
\hline Table 2. Frequency and Percentage Wise Distribution of \\
Victims of Different Religion \\
\hline
\end{tabular}

\begin{tabular}{|c|c|c|}
\hline Area & Frequency & Percent \\
\hline Rural & 32 & 40 \\
\hline Urban & 48 & 60 \\
\hline
\end{tabular}

Table 3. Frequency and Percentage Wise Distribution of Victims of Different Areas

\begin{tabular}{|c|c|c|}
\hline Age Group & Frequency & Percent \\
\hline $10-<13$ & 11 & 14 \\
\hline $13-<15$ & 09 & 11 \\
\hline $15-<17$ & 22 & 27 \\
\hline $17-19$ & 38 & 48 \\
\hline \multicolumn{2}{|c|}{ Table 4. Frequency and Percentage Wise Distribution of }
\end{tabular}

Victims of Different Age Groups

\begin{tabular}{|c|c|c|}
\hline Age Group & Male & Female \\
\hline $10-<13$ & 07 & 04 \\
\hline $13-<15$ & 08 & 01 \\
\hline $15-<17$ & 11 & 10 \\
\hline $17-19$ & 13 & 26 \\
\hline
\end{tabular}

Table 5. Showing Comparison of Age Range with Sex

\begin{tabular}{|c|c|c|c|}
\hline Age Group & Male & Female & Total \\
\hline Young Adolescents & 15 & 5 & 20 \\
\hline Older Adolescents & 24 & 36 & 60 \\
\hline
\end{tabular}

\begin{tabular}{|c|c|}
\hline Occupation & Number of Subjects \\
\hline Student & 43 \\
\hline House Wife & 21 \\
\hline Labour & 13 \\
\hline Other & 03 \\
\hline $\begin{array}{c}\text { Table 6. Frequency and Percentage Wise Distribution of } \\
\text { Victims of Different Occupations }\end{array}$ \\
\hline
\end{tabular}

\begin{tabular}{|c|c|}
\hline Cause of Death & Frequency \\
\hline Hanging & 09 \\
\hline Drowning & 14 \\
\hline Burn Injury & 22 \\
\hline Poison & 08 \\
\hline RTA & 18 \\
\hline Snake Bite & 06 \\
\hline Others & 03 \\
\hline $\begin{array}{c}\text { Table 7. Frequency and Percentage Wise Distribution of } \\
\text { Victims of Different Causes of Death }\end{array}$ \\
\hline
\end{tabular}

\begin{tabular}{|c|c|c|c|c|c|c|}
\hline 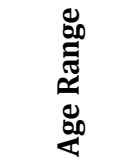 & 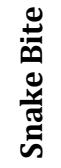 & 吾 & $\begin{array}{l}\tilde{0} \\
\stackrel{\infty}{0} \\
0\end{array}$ & 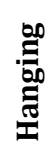 & 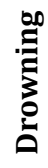 & 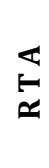 \\
\hline $10-<13$ & 0 & 01 & 01 & 01 & 04 & 04 \\
\hline $13-<15$ & 0 & 01 & 0 & 0 & 04 & 04 \\
\hline $15-<17$ & 04 & 04 & 02 & 04 & 04 & 04 \\
\hline $17-19$ & 02 & 16 & 05 & 04 & 02 & 06 \\
\hline
\end{tabular}

\begin{tabular}{|c|c|}
\hline Manner of Death & Number of Subjects \\
\hline Accident & 47 \\
\hline Suicide & 33 \\
\hline $\begin{array}{r}\text { Table 9. Frequency a } \\
\text { Victims of }\end{array}$ & $\begin{array}{l}\text { age Wise Distribution } \\
\text { lodes of Death }\end{array}$ \\
\hline
\end{tabular}

\begin{tabular}{|c|c|c|}
\hline Manner of Death & Frequency & Percentage \\
\hline R T A & 21 & 45 \\
\hline Drowning & 14 & 29 \\
\hline Burn & 6 & 13 \\
\hline Snake Bite & 6 & 13 \\
\hline Table 10. Table Showing Frequency and Percentage of \\
\multicolumn{2}{|c|}{ Distribution of Accident Cases } \\
\hline
\end{tabular}




\begin{tabular}{|c|c|c|}
\hline Manner of Death & Frequency & Percent \\
\hline Burn & 15 & 46 \\
\hline Hanging & 10 & 30 \\
\hline Poison & 08 & 24 \\
\hline $\begin{array}{c}\text { Table 11. Table Showing Frequency and Percentage of } \\
\text { Distribution of Suicidal Cases }\end{array}$ \\
\hline
\end{tabular}

\begin{tabular}{|c|c|c|c|c|}
\hline Religion & Accident & Suicide & $\begin{array}{c}\text { Chi Square } \\
\text { Value }\end{array}$ & P value \\
\hline Muslim & 23 & 10 & 2.778 & $<0.096$ \\
\hline Hindu & 24 & 23 & 23 & \\
\hline \multicolumn{5}{|r|}{ Table 12. Test of Association between Different } \\
Demographic Factors
\end{tabular}

\begin{tabular}{|c|c|c|c|c|}
\hline Sex & Accident & Suicide & $\begin{array}{c}\text { Chi Square } \\
\text { Value }\end{array}$ & P value \\
\hline Male & 36 & 4 & 32.237 & $<0.001$ \\
\hline Female & 11 & 29 & 3 \\
\hline
\end{tabular}

\begin{tabular}{|c|c|c|c|c|}
\hline Age Group & Accident & Suicide & $\begin{array}{c}\text { Chi Square } \\
\text { Value }\end{array}$ & P value \\
\hline $\begin{array}{c}\text { Young } \\
\text { Adolescents }\end{array}$ & 16 & 4 & & \\
\hline $\begin{array}{c}\text { Older } \\
\text { Adolescents }\end{array}$ & 31 & 29 & 4.969 & $<0.026$ \\
\hline
\end{tabular}

\begin{tabular}{|c|c|c|c|c|}
\hline $\begin{array}{c}\text { Geographical } \\
\text { Area }\end{array}$ & Accident & Suicide & $\begin{array}{c}\text { Chi Square } \\
\text { Value }\end{array}$ & P value \\
\hline Rural & 19 & 13 & 0.009 & $<0.092$ \\
\hline Urban & 28 & 20 & 0.9 \\
\hline
\end{tabular}

\section{DISCUSSION}

A tool of 1100 autopsies were carried out at R G KAR POLICE MORGUE, under the Department of Forensic Medicine \& Toxicology during the study period of 1 year from $1^{\text {st }}$ May 2017 to $30^{\text {th }}$ April 2018 out of which 80 cases were taken involving the adolescent age group on the basis of inclusion and exclusion criteria. The subjects were further sub-divided into two groups of Young Adolescents and Older Adolescents.

Though the world scenario showed the death of male adolescents just surpassed the female adolescents, in our study number of male victims were equal to the number of female victims.

In table No. 3 the victims of urban population were more than that of rural population. The number of deaths reported from urban was more than rural. This is consistent with the $\mathrm{NCRB}^{4}$ ) data which stated that though suicide rate was among the rural people due to socio cultural factors, underreporting of death was to avoiding police investigation. In the Indian Journal of Psychiatry, Rajiv Radhakrishnan(5) rightly quoted that in INDIA 2000 - suicide rate for the country was 10.8 , the rate in urban area was slightly lower at 9.94 .

In table no 4; the main affected age group within the adolescents was 15 to 19 years of age. This is greatly supported by NCRB data 2014 which showed that major accidents faced by adolescents were 14 to 19 years of age and major suicides in this age group were within 14 to 19 years of age.

An interesting fact that was revealed was that, major casualties occurred among the students as a larger part of the subjects belonged to similar age groups. Further it was revealed that though the legal age for marriage for the females is 18 years, in spite of the same, near about $26 \%$ of the subjects were married females.

Table no 7 and 8 showed that accidents were (59\%) were the leading cause of death among adolescents. Spectrum of Unnatural Deaths among the Adolescents: An Autopsy Based Study by Dr. Prabir Chakraborty et al.(6) showed that accidents shared half of the total unnatural death among which road traffic accident was most common. The data is also consistent with the study of Kanchan Tanujie, Mortality among children and adolescents in Manipal, Southern India (2008).(7) In this study road traffic accidents were responsible for maximum mortalities.

As in our study period we did not get any homicidal case, the cases were classified into accidental and suicidal and accidental deaths outnumbered the suicidal deaths.

Table 10 showed that RTA being the most common cause among the accidental deaths followed by drowning and burns. This is supported by different studies. In the Journal of Adolescent Health an article Adolescent Injury Deaths and Hospitalization in Canada -1979 to $2003^{(8)}$ showed that main cause for injury was motor vehicle traffic related injury, followed by drowning.

Whenever the tests of association (Table No. 12) were applied to different demographical parameters, distribution of causes was shown to have significant difference across the sex and age categories. It reinforced the distribution pattern in relation to mode of unnatural death i.e. the older age group was revealed to be significantly more vulnerable towards accidental death. The suicidal deaths were also high among this group.

\section{CONCLUSION}

Suicide is an important cause of death. In our study, accidents covered the major part. Both of them are largely preventable public health problems. Complex array of factors is responsible for both of these but most of them are preventable. Most of the deaths were avoidable. Parenteral monitoring, control of movements, legislation and general concern of the adult population for children's welfare will reduce these largely preventable deaths. Much attention should be paid to institution of preventive measures including aquatic safety education, ensuring supervision near recreational water bodies and instituting and enforcing regulations that make our roads safe.

\section{REFERENCES}

[1] World Health Organization. Suicide rates per 100, 000 by country, year and sex. [Last accessed on 2012 Mar 27].

http://www.who.int/mental_health/prevention/suici de_rates/en/index.html.

[2] Rajagopal S. Suicide pacts and the internet. BMJ 2004;329(7478):1298-9.

[3] Birbal R, Maharajh HD, Clapperton M, et al. Cyber suicide and the adolescent population: challenges of the future? Int J Adolesc Med Health 2009;21(2):1519.

[4] Accidental Deaths and Suicides in India. New Delhi: NCRB, 2000.

[5] Radhakrishnan R, Andrade C. Suicide: an Indian perspective. Indian Journal of Psychiatry 2012;54(4):304-19. 


\section{Jemds.com}

[6] Chakrabarty P, Saren AB, Tudu NK, et al.. Spectrum of unnatural deaths among the adolescents: an autopsy based study. IOSR Journal of Dental and Medical Sciences 2015;14(4):18-24.

[7] Kanchan T, Menezes RG. Mortalities among children and adolescents in Manipal, Southern India. J Trauma 2008;64(6):1600-7.

\section{Original Research Article}

[8] Pan SY, Desmeules M, Morrison H, et al. Adolescent injury deaths and Hospitalization in Canada: magnitude and temporal trends (1979-2003). J Adolesc Health 2007;41(1)84-92. 